\title{
ВИДЫ РОДА SUILLUS GRAY - МИКОРИЗООБРАЗОВАТЕЛИ С PINUS SIBIRICA DU TOUR
}

\author{
М.А. Паламарчук \\ Федеральное государственное бюджетное учреждение науки \\ Институт биологии Коми научного центра Уральского отделения РАН, Сыктывкар \\ E-mail: palamarchuk@ib.komisc.ru
}

\begin{abstract}
Аннотация. В статье представлен обзор литературы о разнообразии видов рода Suillus Gray - микоризообразователей с Pinus sibirica на территории России. На сегодняшний день здесь отмечено шесть видов маслят, образующих микоризу с P. sibirica: Suillus acidus, S. placidus, S. plorans, S. punctipes, S. sibiricus, S. spraguei. Рассмотрены морфологические особенности этих видов, приведены сведения об экологии и географическом распространении в России и в мире. Определены задачи по уточнению объемов некоторых видов.
\end{abstract}

Ключевые слова: Suillus, Pinus sibirica, Россия, сосна сибирская кедровая, Suillus acidus, Suillus placidus, Suillus plorans, Suillus punctipes, Suillus sibiricus, Suillus spraguei

\section{Введение}

Род Suillus Gray (масленок) - самый крупный род семейства Suillaceae (Boletales). Его представители широко распространены в хвойных лесах умеренной зоны. В мире выделяют от 50 (Ainsworth and Bisby's Dictionary..., 2008) до 100 (Smith, 1964; Klofac, 2013; Phylogenetic assessment..., 2016) видов маслят, в России известно порядка 25 видов.

Род Suillus объединяет группу агарикоидных базидиомицетов, имеющих плодовые тела болетоидного типа, состоящие из шляпки с трубчатым гименофором и ножки. Шляпка выпуклая до распростертой, клейкая, слизистая, реже сухая, гладкая или волокнистая, большей частью с легко снимающейся кожицей. Трубчатый слой, приросший или нисходящий на ножку, часто легко отделяющийся от мякоти шляпки, желтый до оливково-коричневого, поры различной формы и размера. У молодых экземпляров гименофор иногда выделяет капли жидкости. Ножка цилиндрическая, выполненная или полая, с кольцом или без кольца, с мелкими железистыми бородавочками или без них. Споровый порошок светло-коричневый, желто-коричневый, оливково-коричневый, оливковый до темно-коричневого. Споры продолговатые, эллипсоидальные, веретеновидные, светло-медовые, коричневые, до 15 мкм длинной. Цистиды булавовидные, цилиндрические или немного вздутые у основания, расположены пучками. Пряжки присутствуют или отсутствуют.

Все виды рода Suillus образуют микоризу с хвойными деревьями, в основном с двухвойными или пятихвойными видами из родов Pinus L. и Larix Mill. Ареалы распространения маслят связаны с ареалами распространения растенийхозяев. Некоторые виды встречаются и в искусственных посадках сосны и лиственницы вне их естественных ареалов.

Сосна сибирская кедровая (Pinus sibirica Du Tour) на территории России встречается в Сибири, на Урале и востоке европейской части. За пределами России растет на территории Монголии и Северного Китая. В Республике Коми популяции $P$. sibirica находятся на северном и западном пределах распространения вида, который включен в региональную Красную книгу (2009). Данные о видах маслят, связанных с этим видом деревьев недостаточны и неоднозначны. Упоминается от одного-трех до шести видов маслят, способных образовывать микоризу с сосной сибирской кедровой. Специальных работ, посвященных этой проблеме, нет. В литературе отсутствуют данные о молекулярно-генетическом анализе видов рода Suillus, связанных с P. sibirica и произрастающих на территории России. Поэтому, очевидно, что эти виды нуждаются в ревизии. На основании современного представления о видовом разнообразии этого рода в статье представлен обзор литературы о видах рода Suillus, образующих микоризу с P. sibirica.

\section{Результаты и обсуждения}

В России на сегодняшний день отмечено шесть видов маслят, растущих в лесах с участием Pinus sibirica. Э.Л. Нездойминого (1969) по материалам с Байкала указывает в качестве симбиотрофов сосны сибирской кедровой пять видов маслят: Suillus placidus (Bonord.) Singer, S. plorans (Rolland) Kuntze, S. punctipes (Peck) Singer, S. sibiricus (Singer) Singer, S. spraguei (Berk. et M.A. Curtis) Kuntze (как Boletinus pictus Peck). Б.П. Васильков (1971) приводит обзор видов рода Suillus, отмеченных в России и образующих микоризу с кедровым стлаником (Pinus pumila (Pall.) Regel) и сосной сибирской кедровой. В качестве микоризообразователей с $P$. sibirica в его работе указаны S. plorans, S. punctipes, S. placidus и S. sibiricus. В более современных публикациях для востока европейской части России и Урала в лесах с участием сосны сибирской кедровой отмечены S. acidus, S. placidus, S.plorans, S. punctipes, S. sibiricus (Переведенцева, 2008; Паламарчук, $2012,2015)$. За Уралом в Западной и Восточной Сибири, на Дальнем Востоке к этим видам до- 
бавляется S. spraguei (как S. pictus (Peck) Kuntze) (Перова, 2001; Сазанова, 2009; Звягина, 2012, 2015; Филиппова, 2017).

W. Klofac (2013), анализируя мировое видовое разнообразие рода Suillus, приводит только три вида микоризообразователей с сосной сибирской кедровой - S. americanus (Peck) Snell f. sibiricus (Singer) Klofac, S. pictus (Peck) Kuntze, S. plorans subs. cyanescens Singer. J. A. Munoz (2005) указывает на возможность образовывать микоризу с P. sibirica только одного вида - S. plorans. В большинстве же зарубежных источников литературы в качестве растения микоризообразователя перечисленных выше видов маслят приводится только P.strobus L. для североамериканских видов (Internal transcribed..., 1996; Klofac, 2013) и $P$. cembra для европейских и голарктических видов маслят (Schmier - und Filzrohrlinge..., 1996; Ronikier, 2002).

Анализ данных литературы выявил шесть видов рода Suillus, способных образовывать микоризу с сосной сибирской кедровой. Приводим характеристику этих видов.

Suillus acidus (Peck) Singer. Отличительными признаками вида являются желтовато-белая слизистая шляпка и ножка с кольцом, покрытая коричневыми железками. В 1964 г. A.H. Smith и H.D. Thiers выделили из этого вида две разновидности - S. acidus var. intermedius A.H. Sm. et Thiers и S. acidus var. subalutaceus A.H. Sm. et Thiers (Smith, 1964). Несколько позже эти разновидности перевели в разряд видов - S. intermedius и S. subalutaceus соответственно. Авторы обосновали выделение новых таксонов различием в цвете шляпки, мякоти ножки, а также вкуce кожицы шляпки плодовых тел. У S. acidus шляпка молодых плодовых тел белая, затем желтоватая, кожица кислая, мякоть в ножке оранжево-желтая и железки на ножке не чернеют. S. intermedius имеет более темную, желто-коричневую шляпку, кислую кожицу, желто-оранжевую мякоть в ножке и чернеющие железки на ножке. S. subalutaceus характеризуется наличием розоватых оттенков в окраске шляпки, желтоватой мякотью ножки и не кислой кожицей. Образцы маслят, собранные на территории Республики Коми в лесах с участием P. sibirica, наиболее подходят под описание $S$. intermedius (Паламарчук, 2015).

Проанализировав источники литературы о разнообразии грибов Северной Америки, откуда этот вид был описан и где широко распространен, обнаруживаем упоминание только видов S. intermedius и S. subalutaceus, очень схожих между собой и отличающихся только вкусом кожицы шляпки (Internal transcribed..., 1996; Bessette, 1997, 2000; Roody, 2003). Однако применение названия S. intermedius незаконно, поскольку оно является более поздним омонимом $S$. intermedius
(Pat.) Kuntze, 1898 (International Code..., 2012, Art. 53.1), поэтому следует использовать S. acidus var. intermedius (Паламарчук, 2015).

S. acidus var. intermedius широко распространен на северо-востоке и севере Северной Америки. Образует микоризу с сосной красной смолистой (Pinus resinosa Sol. ex Aiton), растет одиночно или группами с июля по сентябрь, встречается нечасто (Smith, 1971). В России S. acidus var. intermedius отмечен в Томской области (как $S$. intermedius), где был определен с помощью молекулярно-генетического метода (Вайшля, 2013). Имеются сведения о находке его в Ханты-Мансийском автономном округе (как $S$. acidus) на болоте с участием кедра (Звягина, 2012). На территории Республики Коми вид встречается в Печоро-Илычском заповеднике и южной части национального парка «Югыд ва» (Паламарчук, 2015). Можно предположить, что в России вид сменяет своего симбионта с $P$. resinosa, произрастающего в Северной Америке, на P. sibirica вид, широко распространенный в Сибири. Возможно, S. acidus var. intermedius более часто встречается в Сибири, в лесах с участием сосны сибирской кедровой, но его путают с другими видами рода.

Suillus placidus (Bonord.) Singer. Вид хорошо морфологически отличим от других видов маслят. Характеризуется наличием светлой, беловатой, слизистой шляпки и беловатой ножки, покрытой железками. Кольцо отсутствует. Таксон имеет голарктическое распространение, образует микоризу с пятихвойными соснами: в Европе (Альпах) - с Pinus cembra L., в Северной Америке - с P. strobus, в Китае - с P. massoniana Lamb., в Сибири и на Дальнем Востоке - с P. sibirica, P. koraiensis Siebold et Zucc., P. pumila. Пик плодоношения приходится на август-сентябрь. Встречается одиночно и небольшими группами. В России вид отмечен на Дальнем Востоке (Васильева, 1973), в Сибири (Перова, 2001; Звягина, 2012), на Урале (Переведенцева, 2008; Красная книга..., 2009; Паламарчук, 2012).

В предгорьях Северного Урала, в хвойном лесу с участием сосны сибирской кедровой нами был собран образец рода масленок внешне очень похожий на S. placidus, но с коричневой шляпкой. Типичные плодовые тела $S$. placidus имеют белую шляпку, цвет которой не изменяется. Собранные нами образцы наиболее схожи с S. subalpinus M.M. Moser (Bessette, 2000). Этот вид отмечен только в Северной Америке, где растет в горных лесах с пятихвойными соснами (P. albicaulis Greville et Balfour, P. flexilis E. James) (Moser, 1997). Шляпка слизистая, коричневая, серо-коричневая, по краю шляпки - белая. Гименофор белый, становится желтоватым, поры очень узкие. Ножка белая, покрыта железками, кольцо отсутствует. Вид довольно редкий и предложен 
для включения в международный список редких видов грибов (The Global Fungal..., 2017). Последние филогенетические исследования рода показали, что S. placidus и S. subalpinus образуют один кластер и филогенетически близки друг к другу (Phylogenetic assessment..., 2016). По устным сообщениям коллег из Восточной Сибири (данные Е.А. Звягиной), они встречают подобные образцы маслят и относят их к S. placidus, однако ни в одном из определителей нет сведений о том, что шляпка этого вида может быть коричневой. Очевидно, что необходимо провести дополнительные морфологические и молекулярно-генетические исследования образцов $S$. placidus с территории России.

Suillus plorans (Rolland) Kuntze. Вид характеризуется выпуклой, мясистой, клейкой, желто-оранжевой, желто-коричневой шляпкой. Поры лабиринтовидные, угловатые, желтые. Ножка желтая, покрыта сначала серыми, а затем коричневыми железками. Мицелий в основании ножки розовый. Мякоть желтоватая, оранжево-желтая, не изменяется при повреждении. Вид распространен в Европе, отмечен в Альпах и Татрах (Ronikier, 2002; Munos, 2005; Galli, 2007), образует микоризу с $P$. sibiricus и $P$. cembra. В Рocсии, по мнению Б.П. Василькова (1971), встречается по всей азиатской части, где растет сосна сибирская кедровая. В более современных публикациях сообщается о находках этого вида в Восточной (Нездойминого, 1969; Кутафьева, 1989; Петров, 1991) и Западной (Звягина, 2008) Сибири, Северном Урале (Переведенцева, 2008) и на Дальнем Востоке (Сазанова, 2009).

В 1945 г. R. Singer по материалам с Алтая описал новый вид, по его мнению, близкий к S. punctipes, но с синеющей мякотью - S. cembrae (Sing.) Sing. В качестве отличительных особенностей $S$. cembrae указана желто-коричневая, оранжево-коричневатая с более темными чешуйками шляпка, розовый мицелий в основании ножки и произрастание под $P$. sibirica (Singer, 1945). Позже этот вид исследователь рассматривал как разновидность $S$. plorans ssp. cyanescens (Singer, 1965). О нахождении этого подвида в Магаданской области сообщает Н.А. Сазанова (2009).

Suillus punctipes (Peck) Singer. Шляпка выпуклая, клейкая, охристо-оранжевая, оранжевокоричневая до светло-желтой. Трубочки, приросшие до слегка нисходящих, молодые грязно-коричневые становятся оливковыми до медово-желтых, у молодых образцов покрыты водянисто-белыми каплями жидкости. Поры округлые и угловатые, очень мелкие. Ножка цилиндрическая до булавовидной, светло-охристая, охристо-оранжевая, желто-коричневая. Поверхность ножки покрыта округлыми клейкими беловатыми железками, которые затем становятся коричневыми. Мицелий в основании ножки белый. Мякоть светло-желтая, не изменяется при повреждении. Запах ароматный.

Вид широко распространен в Северной Америке, где образует микоризу с сосной белой восточной - P. strobus (Smith, 1964; Roody, 2003). В России имеются сведения о нахождении этого вида маслят в Прибайкалье (Нездойминого, 1969; Петров, 1991; Горбунова, 2015), Магаданской области (Васильков, 1971; Сазанова, 2009), Приморском крае (Васильева, 1973), на Алтае (Коваленко, 1992), Северном Урале в заповеднике «Басеги» (Переведенцева, 2008) и в Западной Сибири (Звягина, 2008). Считается, что вид образует микоризу с сосной сибирской кедровой (P. sibirica) и кедровым стлаником (P. pumila). А.Н. Петров (1991) сообщает о находке в Прибайкалье формы S. punctipes с интенсивно синеющей на воздухе мякотью шляпки - S. punctipes (Peck) Singer f. cyanescens Nezd.

S. plorans и S. punctipes морфологически очень схожи между собой и нечетко разделяются по морфологическим признакам. В качестве одного из отличий этих видов указан цвет мицелия у основания ножки: у S. plorans - мицелий розовый, у S. punctipes - белый (Васильков, 1971; Klofac, 2013). Однако, Б.П. Васильков (1955), сравнивая образцы маслят из Прибайкалья, собранные под $P$. sibirica, с образцами из Северной Америки, определенными как S. punctipes, заметил, что и у тех, и у других мицелий в основании ножки розовый. Б.П. Васильков (1971) указывает для S.plorans возможность посинения мякоти. Однако, и у того, и у другого вида по образцам из Сибири выделяют формы с синеющей мякотью (Singer, 1965; Петров, 1991).

Последнее филогенетическое исследование большого числа представителей рода Suillus (Phylogenetic assessment..., 2016) показало, что S.plorans из Европы расходится с $S$. punctipes из Ceверной Америки, однако оба вида довольно близки. Образцы маслят из России, образующие симбиоз с P. koraiensis Siebold et Zucc., образовали отдельную группу, близкую к S. punctipes. К coжалению, в данное исследование не включены образцы маслят, образующие микоризу с P. sibiri$c a$. Очевидно, что статус этих видов до сих пор нечетко определен и необходима ревизия образцов этих двух видов.

Suillus sibiricus (Singer) Singer. Шляпка до 10 см в диаметре, округло-выпуклая, выпуклая до распростертой, иногда с бугорком в центре, слизистая, светло-желтая, ярко-желтая, коричнево-желтая, с отдельными отчетливыми красновато-коричневыми волокнистые чешуйками или пятнами. По краю шляпки заметны свисающие бело-желтые лоскутки остатков частного покрывала. Гименофор трубчатый, приросший или слегка нисбегающий, желтый, становится коричнево-желтым. Поры угловатые, вытянутые 
в радиальном направлении. Гименофор у молодых грибов покрыт волокнистым беловато-желтоватым частным покрывалом. По мере роста гриба оно разрывается, оставляя волокнистые свисающие лоскутки по краю шляпки и не всегда четко выраженное колечко на ножке. Ножка цилиндрическая бледно-желтая, покрыта светлокоричневыми, желтовато-коричневыми железистыми бородавочками, которые при повреждении или прикосновении к ножке становятся красновато-коричневыми.

Вид широко распространен, образует микоризу с пятихвойными соснами: в Европе (Альпы, Татры) - с Pinus cembra, P. peuce Griseb. u P. strobus, в Китае - с P. armandii Franch. и P. koraiensis, в Северной Америке - с P. monticola Douglas ex D. Don и P. flexilis. В России S. sibiricus широко распространен в Сибири, в европейской части, отмечен в Пермском крае и Республике Коми. Для Северной Америки описан очень схожий с ним вид $-S$. americanus. По морфологическим признакам эти виды во многом перекрываются. Разные авторы делали попытки разделить их на основании признаков цвета шляпки, отсутствия или наличия кольца на ножке, цвета мицелия в основании ножки. Молекулярные исследования образцов этих видов из Северной Америки и Восточной Азии подтвердили их близкое родство (Phylogenetic and biogeographic..., 2000), однако образцы из Сибири не были включены в анализ. W. Klofac (2013) предложил объединить эти виды в один под названием S. americanus и выделить две разновидности (var. americanus, var. reticulipes) и три формы (f. americanus, f. helveticus, f. sibiricus), что согласуется и с полученными позже молекулярными данными (Phylogenetic assessment..., 2016).

Suillus spraguei (Berk. et M.A. Curtis) Kuntze (= S. pictus (Peck) Kuntze). Шляпка выпуклая, сухая, желтая, желто-оранжевая, покрыта мягкими войлочными чешуйками серо-бурого, красного, винно-красного, красно-коричневого цвета. Край шляпки со свисающими хлопьевидными остатками частного покрывала. Гименофор трубчатый нисбегающий, ярко-желтый, затем желто-коричневый, у молодых плодовых тел закрыт беловатым волокнисто-войлочным покрывалом. Поры радиально вытянутые, угловатые. Ножка цилиндрическая или утолщенная к основанию, с кольцом или кольцевой зоной в верхней части. Поверхность ножки выше кольца гладкая, желтая, ниже покрыта волокнистыми чешуйками как на шляпке. Мякоть желтоватая, на срезе розовеет или краснеет.

S. spraguei широко распространен в Северной Америке, где образует микоризу с P. strobus (Smith, 1971). Считается хорошим съедобным видом (Miller, 2006). В Восточной Азии (Китай, Корея, Япония) образует микоризу с $P$. armandii u P. koraiensis (Phylogenetic and biogeographic..., 2000). B Poc- сии отмечен на Дальнем Востоке (Васильева, 1973) как Boletinus pictus (Peck) Peck) и в Западной Сибири (Перова, 2001; Звягина, 2012, 2015; Филиппова, 2017), в лесах с P. sibirica.

\section{Заключение}

Еще в 1971 г. Б.П. Васильков в работе, посвященной обзору видов маслят, растущих в лесах с пятихвойными представителями рода Pinus (P. pumila, P. sibirica, P. koraiensis), писал: «... многие из отмеченных видов маслят не резко отличаются друг от друга по морфологическим признакам и по произрастанию с разными видами сосен. Необходимы дополнительные систематические исследования о географическом и экологическом различии грибов, произрастающих в Азии и в Северной Америке и связанных микоризным сожительством с разными видами двух подродов рода Pinus» (Васильков, 1971). В результате анализа современной литературы по этому вопросу становится очевидным, что проблема понимания объема видов рода Suillus, связанных с сосной сибирской кедровой, все еще остается открытой. Специальные работы по этой тематике до сих пор не проведены. Многие виды рода Suillus требуют уточнения их статуса и объема.

На территории Республики Коми в лесах с участием Pinus sibirica неоднократно отмечены представители рода Suillus, вызывающие затруднение в их определении. Привлечение морфологических и молекулярно-генетических методов, сравнение полученных результатов с данными о маслятах из Европы и Северной Америки поможет разобраться в этом вопросе. В частности, необходимо уточнить видовую принадлежность образцов, морфологически близких к S.placidus, но имеющих коричневую шляпку. Следует выявить наиболее значимые признаки для разделения близких видов $S$. plorans и $S$. placidus, определить видовую принадлежность образцов, схожих с данными видами и произрастающих на территории Республики Коми под деревьями $\mathrm{Pi}$ nus sibirica.

Работа выполнена при частичной финансовой поддержке колплексной програлмы фундалентальных на учных исследований УрО РАН № 18-4-4-14 «Разнообразие основных компонентов экосистел в широтнол и высотном градиентах западного макросклона Северного и Приполярного Урала» и государственного задания по теле "Структурно-функииональная организация растительных сообществ, разнообразие флоpы, лихено- и ликобиоты южной части национального парка «Югыљ ва» (№ гос. регистрации АAAA-A16116021010241-9).

\section{ЛИТЕРАТУРА}

Вайшля, О. Б. Исследование разнообразия Homobasidiomycetidae в южной тайге Западной Сибири с помощью молекулярно-генетических методов / О. Б. Вайшля, Н. Н. Агафонова, Е. В. Комлева // Молекулярно-генетические подходы в таксономии и эколо- 
гии : тезисы докладов научной конференции, 25-29 марта 2013 г., Ростов-на-Дону. - Ростов-на-Дону : ЮНЦ PAH, 2013. - C. 22.

Васильева, Л. Н. Агариковые шляпочные грибы (пор. Agaricales) Приморского края / Л. Н. Васильева. - Ленинград : Наука, 1973. - 331 с.

Васильков, Б. П. Кедровниковые маслята в СССР / Б. П. Васильков // Микология и фитопатология. 1971. - Т. 5, вып. 2. - С. 184-186.

Горбунова, И. А. Новое о биоте макромицетов Байкало-Ленского заповедника / И. А. Горбунова // Растительный мир Азиатской России. - 2015. - № 4 (20). C. $3-11$.

Звягина, Е. А. Новые данные о макромицетах заповедника "Малая Сосьва" (Ханты-Мансийский автономный округ) / Е. А. Звягина, А. Л. Васина // Микология и фитопатология. - 2015. - Т. 49, вып. 6. C. 349-358.

Звягина, Е. А. Предварительные сведения о видовом составе макромицетов в бассейне р. Салым / Е. А. Звягина // Северный регион: наука, образование, культура. - 2008. - № 2 (18). - С. 23-30.

Звягина, Е. А. Предварительные сведения о микобиоте агарикоидных базидиомицетов Сургутского Полесья / Е. А. Звягина, А. С. Байкалова // Человек и Север: антропология, археология, экология. Вып. 2 : материалы Всероссийской конференции, 26-30 апреля 2012 г., Тюмень. - Тюмень : Изд-во ИПОС СО РАН, 2012. - C. $343-346$.

Коваленко, А. Е. К флоре агариковых грибов Алтайского заповедника / А. Е. Коваленко // Новости систематики низших растений. - 1992. - Т. 28. - С. 6167.

Красная книга Республики Коми / отв. ред. А. И. Таскаев. - Сыктывкар, 2009. - 791 с.

Кутафьева, Н. П. К флоре грибов макромицетов Среднего Приангарья IV / Н. П. Кутафьева // Новости систематики низших растений. - 1989. - Т. 26. - С. 6567.

Нездойминого, Э. Л. Шляпочные грибы лесных сообществ северо-восточного побережья оз. Байкал/ Э. Л. Нездойминого // Микология и фитопатология. 1969. - Т. 3, вып. 2. - С. 124-131.

Паламарчук, М. А. Агарикоидные базидиомицеты Печоро-Илычского заповедника (Северный Урал) / М. А. Паламарчук ; отв. ред. О. В. Морозова. - Сыктывкар, 2012. - 152 с.

Паламарчук, М. А. Первое указание Suillus acidus var. intermedius (Suillaceae, Boletales) для Европы с Северного Урала / М. А. Паламарчук // Новости систематики низших растений. - 2015. - Т. 49. - С. 204212.

Переведенцева, Л. Г. Конспект агарикоидных базидиомицетов Пермского края / Л. Г. Переведенцева. - Пермь : Пермский гос. пед. ун-т, 2008. - 86 с.

Перова, Н. В. Макромицеты юга Западной Сибири / Н. В. Перова, И. А. Горбунова ; отв. ред. Н. В. Седельникова. - Новосибирск : Издательство СО РАН, 2001. - $158 \mathrm{c}$.

Петров, А. Н. Конспект флоры макромицетов Прибайкалья / А. Н. Петров ; отв. ред. А. С. Плешанов. Новосибирск : Наука, 1991. - 81 с.

Сазанова, Н. А. Макромицеты Магаданской области / Н. А. Сазанова ; отв. ред. В. А. Кашин. - Магадан : СВНЦ ДВО РАН, 2009. - 196 с.

Филиппова, Н. В. Видовое разнообразие макромицетов в окрестностях Ханты-Мансийска (средняя тайга Западной Сибири) / Н. В. Филиппова, Т. М. Бульонкова // Динамика окружающей среды и глобаль- ные изменения климата. - 2017. - Т. 8, № 1. - С . 1324.

Ainsworth and Bisby's Dictionary of the Fungi (10th edition) / ed. by P. M. Kirk, P. F. Cannon, D. W. Minter, J. A. Stalpers. - Wallingford : CABI, 2008. - 771 p.

Bessette, A. E. Mushrooms of Northeastern North America / A. E. Bessette, A. R. Bessette, D. W. Fischer.New York, 1997. - 582 p.

Bessette, A. E. North American boletes. A color guide to the fleshy pored mushrooms / A. E. Bessette, W. C. Roody, A. R. Bessette. - New York, 2000. - 402 p.

Galli, R. I Boleti : atlante pratico-monographico per la determinazione dei boleti / R. Galli. - Dalla Natura : Milano, 2007. - 295 p.

Internal transcribed spacer sequences from 38 recognized species of Suillus sensu lato : Phylogenetic and taxonomic implications / A. M. Kretzer, Y. Li, T. Szaro, T. D. Bruns // Mycologia. - 1996. - Vol. 88 (5). - P. 776785 .

International Code of Nomenclature for algae, fungi and plants (Melbourne Code) adopted by the Eighteenth International Botanical Congress Melbourne, Australia, July 2011 (Electronic resource) / J. McNeill, F. R. Barrie, W. R. Buck, V. Demoulin, W. Greuter, D. L. Hawksworth, P. S. Herendeen, S. Knapp, K. Marhold, J. Prado, W. F. Prud'homme Van Reine, G. F. Smith, J. H. Wiersema, N. J. Turland (eds.) // Regnum Vegetabile. 2012. - Vol. 154. - 240 p. - Mode of access: http:// www.iapt-taxon.org/nomen/main.php?page=title

Klofac, W. A world-wide key to the genus Suillus / W. Klofac // Osterreichische Zeitschrift fur Pilzkunde. 2013. - Vol. 22. - P. 211-278.

Miller, H. R. North American Mushrooms: a Field Guide to Edible and Inedible Fungi / H. R. Miller, O. K. Miller. - Guilford : Falcon Guide, 2006. - 359 p.

Moser, M. M. Contribution to the knowledge of North American Suillus species (Basidiomycotina, Boletales) / M. M. Moser // Mycotaxon. - 1997. - Vol. 65. - P. 391402.

Munoz, J. A. Boletus s. l. Fungi Europaei 2 / J. A. Munoz. - Alassio : Edizioni Candusso. - 2005. - 820 p.

Phylogenetic and biogeographic relationships of eastern Asian and eastern North American disunct Suillus species (Fungi) as inferred from nuclear ribosomal RNA ITS sequences / Q.-X. Wu, G. M. Mueller, F. M. Lutzoni, Y.-Q. Huang, S.-Y. Guo // Molecular Phylogenetics and Evolution. - 2000. - Vol. 17 (1). - P. 37-47.

Phylogenetic assessment of global Suillus ITS sequences supports morphologically defined species and reveals synonymous and undescribed taxa / N. H. Nguyen, E. C. Vellinga, T. D. Bruns, P. G. Kennedy // Mycologia. 2016. - Vol. 108, N 6. - P. 1216-1228.

Ronikier, M. Presence and distribution of Suillus plorans in the Polish Tatra mts (Western Carpathians) / M. Ronikier, A. Miskiewicz, P. Mleczko // Acta societatis botanicorum poloniae. - 2002. - Vol. 71, N 3. - P. 235242.

Roody, W. C. Mushrooms of West Virginia and the Central Appalachians / W. C. Roody. - Kentucky, 2003.$520 \mathrm{p}$.

Schmier - und Filzrohrlinge s. 1. in Europa. Die Gattungen Boletellus, Boletinus, Phylloporus, Suillus, Xerocomus / H. Engel, A. Dermek, W. Klofac, E. Ludwig, T. Bruckner. - Weidhausen b. Coburg : Verlag Heinz Engel, 1996. - 268 p.

Singer, R. Die Pilze Mitteleuropas, Band V: Teil 1, Die Boletaceae (ohne Boletoideae) / R. Singer. - 1965. P. 1-131. 
Singer, R. The Boletineae of Florida with notes on extralimital species. II. The Boletaceae (Gyroporoideae) / R. Singer // Farlowia. - 1945. - Vol. 2. - P. 223-303.

Smith, A. H. A contribution toward a monograph of North American species of Suillus (Boletaceae) / A. H. Smith, H. D. Thiers. - Michigan, 1964. - 163 p.
Smith, A. H. The Boletes of Michigan / A. H. Smith, H. D. Thiers. - Michigan, 1971. $-428 \mathrm{p}$.

The Global Fungal Red List Initiative, 2017 (Electronic resource). - Mode of access: http://iucn.ekoo.se/ iucn/species_view/442468.

\title{
SPECIES OF THE GENUS SUILLUS GRAY - MYCORRHIZAL WITH PINUS SIBIRICA DU TOUR
}

\author{
M. A. Palamarchuk \\ Institute of Biology of Komi Scientific Centre of the Ural Branch of the Russian Academy of Sciences, Syktyvkar
}

\begin{abstract}
Summary. The genus Suillus Gray is the largest genus of the Suillaceae family. All species of this genus form mycorrhizas with coniferous trees, mainly with two- or five-needle species from Pinus L. and Larix Mill. So, the distribution areas of Suillus species are associated with the distribution areas of the host trees.

In Russia, Pinus sibirica Du Tour occurs in the east of the European part, Ural and Siberia. Outside Russia, $P$. sibirica grows at the territory of Mongolia and northern China. In the Komi Republic, there are northern and western distribution borders of $P$. sibirica and so, this species is included in the regional Red Data Book. The data on the species of fungi associated with Pinus sibirica are inadequate and ambiguous.

Literature analysis of Suillus world diversity indicates only six species that form mycorrhiza with $P$. sibirica Suillus acidus, S. placidus, S. plorans, S. punctipes, S. sibiricus, S. spraguei. All the species are found in Russia. Suillus acidus, S. placidus, S. plorans, S. punctipes and S. sibiricus are noted from the Northeast European Russia and Ural. In western and eastern Siberia and the Far East, S. spraguei (as S. pictus) also occurs. This review is aimed at the analysis of the morphological features of Suillus species, their ecology and geographical distribution in Russia and in the other world.

Analyzing the up-to-date literature, it is clear that the problem of understanding the taxonomy of the genus Suillus associated with $P$. sibirica is still open. Special studies devoted to this subject have not been conducted so far, and there are no molecular genetic data for these species. So, the status and volume of many Suillus species should be clarified from the taxonomical point of view.
\end{abstract}

Key words: Suillus, Pinus sibirica, Russia, Suillus acidus, Suillus placidus, Suillus plorans, Suillus punctipes, Suillus sibiricus, Suillus spraguei 